\author{
Vidar Fagerheim Kalsås \\ The Norwegian Center for Holocaust and Minority Studies \\ Jenni Helakorpi \\ University of Helsinki
}

DOI: http://dx.doi.org/10.5617/adno.8378

\title{
The curriculum as a controversial issue: Negotiations about the position of Norwegian Romani in education and society
}

\begin{abstract}
National curriculum and teaching materials play a significant role in how students discuss and learn to understand issues which are controversial in society. However, the ways curriculum content aims to answer to rapidly changing political landscapes also influence the phenomena that the curriculum aims to unpack. In this article, we analyse one such phenomenon. Our aim is to investigate how the curriculum content about the Romani people in Norway has been used in the ongoing negotiation of the group's position in Norwegian education and society. In the Green Paper NOU 2015: 7 Assimilation and Resistance - Norwegian policies towards Tater/Romani people from 1850 to the present, it is suggested that the curriculum should include more knowledge about Romani.

In this article, we analyse the consultation process that was initiated after the publication of the Green Paper. We focus on how the submissions by individuals and institutions are discussing the curriculum content concerning the Romani. Our analysis illuminates how a specific curriculum content can have effects and play a part in ongoing issues outside of the school context. We have focused on reading the positions on the curriculum in light of the contexts of historical justice for the Romani, and of multiculturalism in education. The analysis illustrates that, how controversial societal issues are handled in the curriculum, can impact societal processes outside of the classroom.
\end{abstract}

Keywords: controversial societal issues in education, historical justice in education, multiculturalism in education, Romani, curriculum studies

\section{Læreplanen som ei kontroversiell sak: Forhandlingar om romanifolket sin posisjon i utdanning og i samfunnet}

\footnotetext{
Samandrag

Nasjonale læreplanar og undervisningsmateriell spelar ei viktig rolle i korleis elevar diskuterer og lærer om kontroversielle spørsmål i samfunnet. Samtidig vil måten læreplanen sitt innhald siktar mot å svare på politiske landskap i rask endring, også påverke dei fenomena som læreplanen omhandlar. I denne artikkelen analyserer vi eit slikt fenomen. Målet er å undersøkje korleis læreplanen sitt innhald om romanifolket i Noreg har blitt nytta i pågåande forhandlingar om gruppa sin posisjon i norsk skule og samfunn. I NOU 2015: 7 Assimilering og motstand - Norsk politikk overfor taterne/romanifolket
} 
fra 1850 til i dag blir det foreslått at læreplanen bør inkludere meir kunnskap om romanifolket.

I denne artikkelen analyserer vi høringsrunden som blei initiert etter publiseringa av NOU 2015: 7. Vi fokuserer på korleis høringssvara frå både individ og institusjonar diskuterer læreplanen sitt innhald om romanifolket. Vår analyse kastar ljos over korleis eit konkret innhald i læreplanen kan ha effekt og spele ei rolle i pågåande prosessar utanfor skulekonteksten. Vi har fokusert på korleis dei ulike posisjonane til læreplanen sitt innhald kan lesast i ljos av kontekstane om historisk rettferd for romanifolket og av multikulturalisme i utdanning. Analysen illustrerer korleis måtane som kontroversielle samfunnsspørsmål blir handsama på i læreplanen, også kan påverke samfunnsprosessar som går føre seg utanfor klasserommet.

Nøkkelord: kontroversielle samfunnsspørsmål i utdanning, historisk rettferd i utdanning, multikulturalisme i utdanning, romanifolket, læreplanstudiar

\section{Introduction}

The educational system has historically been an important part of the Norwegian state's minority policy. The school system was for example a vital tool in the norwegianisation policy towards the Sami and Kven minorities in the $19^{\text {th }}$ and $20^{\text {th }}$ century (Niemi, 2017). When the Norwegian Government introduced a new minority policy in 2000, which aimed to protect and develop the culture of the groups defined as national minorities, the educational system was again mobilised and seen as an instrument for spreading knowledge about the national minorities (Ministry of Local and Regional Affairs, 2000). The relatively small group of Romani/Tatere was among the groups defined as national minorities, but this categorisation was met with ambivalence among the Romani community. ${ }^{1}$ Some among the small Romani community saw this as an opportunity to restore cultural traditions and a common language, but there were also some who voiced opposition against becoming categorised by the Government.

This minority policy had a visible impact on educational policy, particularly at the curriculum level: Knowledge about Norwegian national minorities was added to the curriculum during the curriculum reform Kunnskapsløftet in 2006 (Utdanningsdirektoratet, 2006a, 2006b). Adding knowledge about minoritised groups to school contents can be described as characteristic for multicultural education (Banks, 2009; Gillborn, 2006; Helakorpi, 2019). This approach to multiculturalism in education has been criticised for being superficial and for not tackling discrimination, racism and uneven power relationships in education (Gillborn, 2006; Kumashiro, 2002). Furthermore, it has been criticised for quickly

\footnotetext{
${ }^{1}$ There are no censuses based on ethnic affiliation in Norway, which makes the number of people identifying as Romani uncertain. There are estimates of 4000-10000 people (NOU 2015 7, p. 18). In the Norwegian policy papers, the minority has been named as "Romanifolket/taterane", which can be translated into the Romani people, the Romani or the Travellers. Within the group, the issue of which name to use, and in which contexts, has been contested for several decades (see Halvorsen, 2004). For linguistic clarity we have chosen to translate the different names used in the policy documents and in the hearing submissions into "Romani".
} 
ending up essentialising the minoritised groups and making simplified narratives of complex histories and identities (Kumashiro, 2002; Helakorpi, 2019).

Ideas of multicultural education and the category of national minorities have also impacted the research on questions about cultural difference and majorityminority relations in the Norwegian school system. For some researchers, the category of national minority has been a precondition for their research. Even though there might be a recognition of a minority as a diverse group (for example Moen, 2009, p. 227), what appears in the text is often a unified national minority subject which expresses common interests and intentions (Moen, 2009; Moen \& Lund, 2010; Lund \& Moen, 2013; Askeland \& Aamotsbakken, 2016). This form of essentialism, strategic or not, will quite easily overlook the diversity of interests and intentions that might be in play, both from people that are labelled or identify with the minority, or from actors that neither are labelled nor identify with the minority identity (Helakorpi, 2019). As Gayatry Chakravorty Spivak has pointed out, what appears as a subject might actually be the subject-effect (Spivak, 1988). Part of our aim in this article is thus to open up one of the groups categorised as a national minority in Norway, the Romani, and challenge some of these preconditions empirically by analysing the following case:

In 2015 the Norwegian Government published a Green Paper NOU 2015: 7 Assimilation and Resistance - Norwegian policies towards Tater/Romani people from 1850 to the present, considering the past and present of the Norwegian Government's policy towards the Romani. The Green Paper likewise emphasised the lack of knowledge about Romani culture and history in society, and the prevalence of prejudices against the group was described as a consequence. A suggested measure to tackle this problem was to add content about Romani in schools. The Green Paper was submitted to a public hearing where anyone could give their opinion of it, but where people with a Romani background were particularly called on. Like in 2000, when national minorities were defined, many Romani found the Green Paper uncomfortable and even offensive. The idea of more content about Romani in the curriculum was fiercely opposed by many. This opposition brings forth how curricula are sites where political controversies are negotiated (Lappalainen et al., 2019), and how the curriculum content is entangled in societal power relations. Thus, the prevalent and widely accepted approach to multiculturalism in education was contested by individuals who were pleading the Norwegian society to leave the Romani alone and not add anything about them in the curriculum.

The aim in this article is not restricted to investigating the negotiations about the curriculum as such, but to analyse how negotiations about the curriculum are part of processes concerning the positions of the Romani in contemporary Norwegian society. By analysing the hearing submissions from NOU 2015: 7 Assimilation and Resistance, we try to answer our main research question: How is the curriculum used in negotiations over the position of Norwegian Romani in 
society? To operationalise this question, we have further formulated two research questions:

1) What is the role of the curriculum in the hearing submissions to NOU 2015: 7? 2) What are the main stances and views on the curriculum's content on the Norwegian Romani, articulated in the hearing submissions?

We aim to answer these questions through the following structure: We begin by introducing how national minorities became part of the curriculum content in Norway, viewing that as part of the emergence of multiculturalism in Norwegian education. This is followed by a description of the development of a political process for achieving historical justice for the Romani, and how curriculum became intertwined with this process. We then introduce our data and analytical approach which are followed by a description of the results, a discussion of the results in light of the context of multiculturalism in education and the process of historical justice, and end with a section on conclusions.

\section{National minorities as curriculum content}

In 1998, the Norwegian Storting (Parliament) ratified The Council of Europe's Framework Convention for the Protection of National Minorities (FCNM). The ratification led to the implementation of a new category in Norwegian minority policy, the category "national minority". Central in the definition of this category, were groups with "ethnic, linguistic, cultural and/or religious characteristics, which make them distinctive from the rest of the population in that particular state" (Ministry of Foreign Affairs, 1998, p. 11) ${ }^{2}$, and have kept these characteristics within the borders of the nation-state over a long-lasting period of time. The Norwegian Government defined the groups Jews, Kvener, Roma, Romani (Tatere/travellers) and Forest Finns as national minorities. The Sami was also recognised as falling under the definition, but the Sami Parliament stated that they did not want to change their status as an indigenous people, which gave the group a different set of rights under the ILO-169 convention (Ministry of Local and Regional Affairs, 2001). A new minority policy was designed towards these groups in a White Paper published in 2000 (Ministry of Local and Regional Affairs, 2001). The implementation of the category of "national minority" in addition to the existing "indigenous people", is central in what has been termed a minority hierarchy in Norwegian minority policy, where some ethnic minorities are acknowledged rights and protection, while others are not (Brochmann, 2002, pp. 44-45).

The ratification of The Council of Europe's (1995) FCNM and the implementation of the new minority policy did also have implications for the Norwegian

\footnotetext{
${ }^{2}$ Quotations from Norwegian documents have been translated by the authors.
} 
school system and the curriculum content. Article 12 in FCNM has formulations that particularly address education: " 1 . The Parties shall, where appropriate, take measures in the fields of education and research to foster knowledge of the culture, history, language and religion of their national minorities and of the majority" (Council of Europe, 1995, p. 4). This was followed up in the Norwegian White Paper as: "The school is a central societal arena where the national minorities should be visible. It can be a channel where society conveys knowledge about the national minorities to children and teenagers, and eventually to the rest of the majority population. It is therefore important that schools convey a truthful and unprejudiced image of the national minorities in today's society and their situation in Norway in the past" (Ministry of Local and Regional Affairs, 2000, p. 60).

A national curriculum reform was introduced in 2006, in which the impact of the national minority policy was visible. The category "national minority" was explicitly used in the competency goals in social sciences for primary school, and in history for upper secondary school (Utdanningsdirektoratet, 2006a, 2006b). ${ }^{3}$ The curriculum was thus given a role in the policy towards national minorities, but the implementation also meant that the minority hierarchy was brought into the curriculum, with a distinction between indigenous people, national minorities and immigrants (Morken, 2009).

The introduction of the category might also be seen in relation to the international development of multicultural or intercultural education, both as pedagogy and as a discourse in school reform (Banks, 2009; Allemann-Ghionda, 2009). Terms such as diversity and multiculturalism were already present in Norwegian educational policy and discourse (Westrheim \& Tolo, 2014), but often with a somewhat fuzzy or undefined content (Westrheim \& Hagatun, 2015). This might in part explain why the category was introduced without any controversy.

It is difficult to say precisely how these educational goals have been transformed into instructions and learning in the classroom, or what knowledge about national minorities the students actually take with them from the classroom. Two reports from 2014 by Midtbøen, Orupabo and Røthing give some insight into this, where they have analysed textbooks and interviewed teachers and students. Their general finding is that the textbooks are lacking accounts about the national minorities and that the subject often is set aside in the classroom, in order to prioritise issues that are more present in political and societal discussions (Midtbøen, Orupabo, \& Røthing, 2014a, 2014b). The Norwegian Directorate for Education and Training and The National Centre of Multicultural Education have produced teacher manuals and educational resources about the national minorities, with the purpose of improving this situation (Utdanningsdirektoratet, 2014).

\footnotetext{
${ }^{3}$ There is currently an ongoing curriculum reform in Norway, which is being implemented from 2020 until 2023. The term "national minority" is kept in the curriculum for social sciences.
} 


\section{The politics of historical justice and Romani identity}

During the second half of the $20^{\text {th }}$ century, there have been a growing number of cases where groups of victims of abuse and violence in the past have demanded acknowledgement and reparations for historical atrocities they have endured. The specificities of the cases and the groups have varied, but in many countries citizens and leaders have had to face injustices from their nations' past, when the victims or descendants of victims have demanded apologies and/or reparations (Neumann \& Thompson, 2015, p. 6). This global phenomenon can be described as a way of doing politics, a politics of historical justice, where atrocities or oppression in the past becomes a ground for political action in the present. The aim that guides the actors in these processes is usually to restore some form of justice and/or achieve reconciliation between the communities of victims and representatives of the former oppressor (Bevernage, 2015, p. 334). ${ }^{4}$ As an acknowledgement of the injustices in the past is central in this form of politics, the curriculum has become a place where this form of politics can be articulated. A politics of historical justice has characterised several areas of Norwegian political discourse since the 1990s and has led to a revised interpretation of the state's historical relationship to ethnic minorities, among them the Romani.

This new public interpretation and interest in the state's history were also grounded in new historical research on the state's policy of assimilation (see Hvinden, 2000). From the second half of the $19^{\text {th }}$ century, the Norwegian state developed a specific assimilation policy that targeted people who were labelled as "vagabonds" (omstreifere) (Hvinden, 2000; Haave, 2017). At the turn of the $20^{\text {th }}$ century, the state delegated the execution of this policy to the private missionary organisation, Norwegian Mission among the Homeless, whose central instruments were placing children from Romani families in foster care or orphanages and the running of a labour colony in which Romani families were to learn a sedentary lifestyle (Pettersen, 2005). These policies were gradually dismantled during the 1970s and 1980s, after they had drawn negative media attention.

In the early 1990s, an ethnopolitical movement among the Romani minority started to form, with the establishment of several identity-based NGOs. An important political aim for this movement was to create recognition for the damage that the state's assimilation policy had inflicted upon the Romani community. The movement fought both for individual compensation for persons who had experienced neglect or abuse under the care of the Norwegian Mission among the Homeless, and for the state and the Church of Norway to acknowledge their responsibility in these abusive policies (Halvorsen, 2004, pp. 35-37). The movement has also worked for a redefinition of "Romani" as a collective identity, inscribing it with a common culture, language and history (Kalsås, 2015). But the movement has also encountered resistance against this project from within the

\footnotetext{
${ }^{4}$ The form of politics has been referred to by different names, such as the "politics of regret", "reparation politics" and "retrospective politics".
} 
Romani community. This was most clearly articulated when the Romani were defined as one of the Norwegian national minorities in 2000 (Ministry of Local and Regional Affairs, 2000, pp. 45-46). For some in the community, this was felt as a continuation of the history of controlling and policing the group (Halvorsen, 2004, p. 56).

The movement can be said to have achieved some of its goals from the turn of the century, when both the Norwegian Government and the Church of Norway delivered public apologies for their responsibility in the historical abuse of the group. The Government's public apology was followed up in 2004 by a fund of 75 million NOK for developing Romani culture and language, and by a museum department and exhibition, which was opened in 2006. At the end of the 2000s, several Romani activists voiced criticism of the Government's apology. They felt that the apology had not been clear enough and that it had not been made known in the Romani community. Several Romani organisations and supporting institutions therefore sent a joint letter to the current Prime Minister Jens Stoltenberg, with four central demands. Among them was a demand for a truth and reconciliation commission that should investigate the historical abuse towards the Romani. The Government's answer was not a full-scale truth and reconciliation commission, but a public commission, known as the Tater-/romaniutvalget. After four years work, the commission delivered the report in the form of a Green Paper, NOU 2015: 7 Assimilation and Resistance - Norwegian policies towards Tater/ Romani people from 1850 to the present, to the Minister of Local Government and Modernisation during a formal ceremony at the University of Oslo's aula, on the $1^{\text {st }}$ of June 2015.

In the report, the commission concludes that the Norwegian policies towards the Romani had been "wrong and destructive", and that the policies had and still have dire consequences for the Romani. One of the contemporary issues that the commission points out is that "there is a lack of knowledge about Tatere/Romani culture and history in society, and there exists negative prejudice against the group. [...] There is little dissemination of knowledge about Tatere/Romani culture and history in kindergarten, primary school and teacher education, and they are therefore invisible as a group in today's society» (NOU 2015: 7, p. 5). The commission suggested that knowledge about the Romani should be increased in teacher education and that extra efforts should be initiated in order to increase education about this minority.

The commission further concluded that the history of assimilation of the Romani has the following contemporary consequences: There is a general lack of knowledge about the Romani culture and history in society, and because of that, there are widespread prejudices towards the Romani. For contemporary Romani, they are still struggling with the wounds from the loss of language and culture and from disrupted family ties. Because of the policies in the past, the Romani community has a lack of trust and sometimes fear of the Government and its institutions. The commission further found that the process of reconciliation 
between the Government and the Romani has not been satisfactory so far (NOU 2015: 7, pp. 7-8). Thus, the commission has several suggestions for how to counteract the consequences of the past policy, among which one of them is the increase in knowledge about Romani in schools:

The commission will further point out that the knowledge about national minorities in general, and Tatere/Romani in particular, should be increased in schools. It is important that the Directorate for education and NAFO [The National Centre of Multicultural Education] follow up and ensure that the schools and kindergartens make themselves familiar with the booklet on national minorities. In addition, the commission sees it as key that knowledge about national minorities is included in teacher education. (NOU 2015: 7, p. 137)

After the publication, the report was sent out on a consultative hearing, which is the normal procedure before the Government proposes a new bill or a White Paper for the Parliament. In the call for contributions, The Ministry of Local Government and Modernisation particularly encouraged: "In order to get the best possible basis for the further work, we will particularly welcome contributions from all parts of the Romani/Tatere community. We would very much like contributions from individuals with a background from Romani/Tatere, in addition to the organisations for the minority.” (Ministry of Local Government and Modernisation, 2015). In addition to written contributions, the Ministry also arranged ten meetings around the country, where verbal contributions could be given. These hearing contributions constitute the empirical data for this article.

The report and the following consultative hearing have not resulted in any specific measures or policy. This might be partly explained by the varying and contradictory content of the hearing responses. It is still likely that the report and the consultative hearing will be part of the foundation for a new Parliamentary Report on national minorities that the Government is currently working on. The Report is expected to be presented to the Norwegian Parliament in December 2020.

We have outlined two central contexts for interpreting the empirical data in this and the previous section: A context of multiculturalism, which is expressed in policy documents such as FCNM, Stortingsmelding $n r .15$ 2000-2001, and the curriculum reform Kunnskapsløftet from 2006, and a context we term the "politics of historical justice" which is most clearly expressed in NOU 2015: 7 Assimilation and Resistance. We have found it useful to make this contextual distinction between multiculturalism and politics of historical justice, because it allows us to sharpen the analysis of the consultative hearing. As the aim of this article is to explore how the curriculum is used for negotiating the position of the Romani, stances and arguments about the curriculum need to be understood in relation to the two central contexts in which the Romani appear as subjects. Our hypothesis is that different stances on these questions will most likely also see different uses of the curriculum. 
A few words about the differences and similarities of the contexts are needed for further clarification. Multiculturalism as a normative position and ideology has been much debated within academia (Bangstad, 2011). In public discourse and policies, "multiculturalism" has become a heterogeneous term, deployed globally but with no stabilised and unified meaning. In this article, we understand multiculturalism as a delimited context in forms of discussions, policies and strategies that aim to handle the issues and problems that cultural diversity and multiplicity in society can create (Hall, 2000, p. 209). Within this context of multiculturalism in Norway, there have been different policies and strategies that have dominated in different areas and towards different minority groups, but the policies towards national minorities have been consistent since the category was introduced in 2000, inspired by a liberal form of multiculturalism (Taylor, 1992; Kymlicka, 1995). As a subsection of this context, there is also the question about diversity in education in Norway, where ideas about multiculturalism in education have influenced thoughts and practices (Banks, 2009; Morken, 2009; Westrheim \& Tolo, 2014; Westrheim \& Hagatun, 2015; Schjetne \& Skrefsrud, 2018).

The context we term "politics of historical justice" can be understood as discussions, policies and practices about how society today should deal with atrocities and oppression that were conducted in the past. In contrast to multiculturalism, there is no consistent ideological foundation for the political answers to this issue. But processes of historical justice will always build on certain normative premises, such as a notion of "justice" and evaluations of how actions and events in the past should influence our actions and policies in the present. These two contexts can be named and analytically distinguished, but it is important to underline that they are in many instances interwoven. Many discussions about how to deal with cultural diversity also contain arguments about how ethnic minorities have been treated in the past, while many processes of historical justice concern the ancestors or still living members of contemporary ethnic minorities.

\section{Methods}

\section{Public hearing as data}

To establish a commission to produce an NOU is usually the first step in the process of new legislation or policy in the Norwegian parliamentary system. After the publication of the NOU, it is customary that the Ministry organises a consultative hearing, in which interested parties are invited to respond to the commission's findings and suggestions. The NOU and the hearing responses constitute the foundation on which the Ministry then creates a Parliamentary Bill or a Parliamentary Report (Tellmann, 2018). The consultative hearing is thus part of the democratic processes in Norway and is ideally a process where stakeholders can express their opinions and influence policy. This makes the consultative hearing an interesting site for political analysis, also for the scope of our analysis. 
As we are interested in how definitions of curriculum contents play a role in the negotiations about the position of Romani in Norway, the parts that discuss curriculum in the consultative hearing can thus be analysed to map out if and how the curriculum is viewed as controversial by stakeholders, and how these controversial issues in the curriculum connect to other parts of the state's policy towards the Romani. For our project, this consultative hearing gives us an entrance to study the relationship between the curriculum, multiculturalism as educational policy and political processes of historical justice.

However, using a consultative hearing as empirical data has its limitations, particularly when it comes to identifying the power or influence of the actors involved. By studying only the hearing, it is not possible to say anything about the actual influence that different actors have on any final policy. The range of political positions is further limited by how the NOU frames the policy area and what is identified as important issues. Furthermore, the hearing process will potentially exclude stakeholders that are not able to produce a written statement. In this particular case, the Ministry attempted to lower the bar for participation in the hearing process, by encouraging individuals with a Romani background to contribute, and by arranging ten public meetings. The oral statements from the meetings were summarised and written down by the Ministry, and they are consequently part of our empirical material.

The Ministry further tried to lower the bar for participation by allowing hearing statements to be sent in anonymously. This might have led to an increase in statements with a threatening or harassing content, aimed at named individuals. The Ministry censored parts of any statement that included such content. In addition, some statements are conspicuously similar in their wording, which raises the question of who is actually speaking in the hearing process. This is not a major problem for our study, since we are not interested in who the specific individual behind each written contribution is, or the representativeness of the individuals. What we are aiming at, is to map out what positions the Romani are ascribed in the hearings. This can be done without the knowledge of the authors' identities. But what is of interest in our analysis, is the textually performed identity of the author and what subject position each hearing thus takes. We have operated with three main author categories: Romani, for statements in which the author of the text presents themself as belonging to the Romani community. Public institutions, for statements that were sent from well-known institutions or organisations, and Other for statements where the textual author did not fit the two above.

Doing research on political processes concerning the minority-majority relations always has a normative dimension; description of the positions the Romani are ascribed in the hearing will be influenced by our notions and assumptions of how minority-ness can and should be handled in our society. But it also entails a dimension of research ethics, which in our case became increasingly apparent after we started to read and analyse the hearing submissions. One of the returning arguments in the position that we have labelled as Against, is that there should be 
no further research conducted on the Romani people. It may thus seem like a paradox that we are turning these expressions of protest against further research into data for research. It should be noted that we are not studying "the Romani" as a research object, but rather the interconnections between stances on the curriculum and political contexts of multiculturalism in education and the politics of historical justice. And as far as these voices are expressed in the public and as part of a parliamentary process, we see it as important that they are also brought into the research on curriculum and educational policy.

\section{The process of analysis}

We started our analysis by finding the statements which discussed the curriculum content. By searching through the statements for the words 'skole' (school) and 'utdanning' (education), we found that 132 of the statements $(\mathrm{N}=231)$ mentioned or discussed the curriculum. Statements that discussed other aspects of the Romani-school relation than the curriculum content were excluded from our selection. First, we categorised the selected statements in three categories based on their general position in relation to the NOU. The statements that primarily supported the findings and proposals in the NOU were categorised as pro, the statements that opposed the proposals were categorised as against, and the statements that expressed both support and opposition were categorised as ambivalent. After collecting and categorising all the comments, we started to read closely how these different positions were constructed in the statements and what role the issue of the curriculum played for the different positions.

\section{The results: pro, against and ambivalent}

In our initial analysis of the material, we identified two distinct positions in the hearing submissions. In the following, we describe these positions as ideal types, and we highlight the arguments that are presented under each type. The types pro and against constitute the outermost positions on a continuum, which can be divided into three broad categories: pro, ambivalent and against. Table 1 shows the number of hearing submissions in each category and the number of pro, against and ambivalent submissions from each author category.

Table 1. Number of Pro, Against and Ambivalent hearing submissions

\begin{tabular}{|l|l|l|l|}
\hline $\mathrm{N}=132$ & Romani $(\mathrm{N}=105)$ & Institution $(\mathrm{N}=12)$ & Other $(\mathrm{N}=15)$ \\
\hline Pro $(\mathrm{N}=44)$ & $\mathrm{N}=21$ & $\mathrm{~N}=11$ & $\mathrm{~N}=12$ \\
\hline Against $(\mathrm{N}=75)$ & $\mathrm{N}=74$ & $\mathrm{~N}=0$ & $\mathrm{~N}=1$ \\
\hline Ambivalent $(\mathrm{N}=11)$ & $\mathrm{N}=9$ & $\mathrm{~N}=1$ & $\mathrm{~N}=1$ \\
\hline Unclear $(\mathrm{N}=2)$ & $\mathrm{N}=1$ & $\mathrm{~N}=0$ & $\mathrm{~N}=1$ \\
\hline
\end{tabular}




\section{“More knowledge about Romani in schools!"}

The first position is labelled Pro. This position underlines the importance of the conclusions in the NOU and is in general positive to the suggestions for measures that are put forward. The position rests on the historical narrative that the NOU presents. A common element with the measures that are highlighted in this position, is how they are means to counteract the historical wrongs of the past, by refuting prejudices constructed in the past against Romani, by contributing to reconciliation between the Majority (the State) and the Romani, or by revitalising a culture that was illegitimately taken away from its people. The position can thus be described as an attempt to restore some notion of justice.

An example of this position is to be found in The Norwegian Helsinki Committee submission. The Committee supports the conclusions made in the NOU, and they are supporting the suggestions for measures. Amongst them are the strengthening of teaching about Romani history and culture:

The teaching must give an introduction to the minority's culture and the cultural contribution the minority has given to the larger society, and the policy and prejudice that they have been met with in Norwegian society and from Norwegian authorities. The teaching must especially give knowledge and understanding for the policy and the attitudes that apply today.

What subject position do the submissions in this category take? Two types of submissions are particularly visible. One of them is public institutions, often within or connected to the Government. 11 of the 132 submissions that we have analysed fall into this category. These institutions take note of the conclusions in the NOU, and their responses are directed towards how their institution has contributed and can contribute in the future, towards achieving the goals that the NOU puts forward. The Directorate for Education is an example of this position. The Directorate highlights in its submission how they are aware of the lack of knowledge about the Romani among teachers and students in schools, and continues to present the measures the Directorate has taken to counteract this situation.

The second type are contributors presenting themselves as Romani. 21 of the 132 submissions fall into this category. These contributions are generally positive to the result of NOU 2015: 7, but are pointing towards the need for further developing the Romani community and for Romani participation in relevant policies. They are highlighting the importance of Romani participation in the measures, such as in the production of learning resources or in different educational activities in schools. This will ensure that the knowledge about the Romani is correct. The further dissemination of knowledge should be thoroughly grounded in the Romani community and preferably communicated by Romanies. Many are also arguing for a further strengthening of the Romani organisations and institutions, so that they can contribute to the dissemination of knowledge. 


\section{"I am against"}

The other category is labelled Against. The submissions that take this position are against the policies that categorise the Romani as an ethnic group or a national minority. They are sceptical of organising, and they are particularly critical towards the current Romani organisations. The slogan "imot" (against) is commonly used. It should be underlined that these statements do not refute the historical narrative presented in the NOU, but they do not see the need for any further measures. They do not want any research on Romani issues, and no public dissemination of knowledge about Romani culture or history. It is pointed out that they have the same rights as any other Norwegian citizens and that they view their Romani culture and language as a private matter that does not belong on display in the curriculum. Of the 75 submissions we can describe as Against, all but one present themselves as Romani. This seems to suggest that there are at least two conflicting positions within the Romani community. The dissemination of knowledge about Romani in school and kindergarten is a recurring theme in these submissions. Three arguments are put forward. The first is that teaching about the Romani culture and history will bring attention to children with a Romani background, that they will be seen as different and that this will further lead to the children being bullied in school. The opposition towards knowledge about Romani culture and history in the curriculum, is framed as an attempt to shield Romani children from prejudice and bullying. The second argument is the continuous attention to the oppressive assimilation policies in the curriculum, which in the Against statements is seen as placing the Romani as victims. And a third argument is that the Romani are such a heterogeneous group that it is not possible to define a common culture that can be disseminated.

\section{Ambivalent}

As mentioned, the ideal types of Pro and Against can be understood as outermost positions on a continuum. This means that the submissions that we have categorised as either Pro or Against do not necessarily entail all the traits and arguments described above, but they have at least expressed one of the arguments mentioned. Some of the submissions did not fall into any of the two categories, or they contained arguments from both the Pro and Against positions, expressing more of a contradictory or ambivalent position. We have thus categorised these submissions under the label of "ambivalent". We have found 11 of our submissions belonging to this category. Since the majority of the submissions can be categorised as either Pro or Against, and since we are particularly interested in understanding the controversy, our further discussion focuses on the Pro and Against positions. 


\section{A controversial curriculum content: Multiculturalism in education, historical justice, and the counter-discourse}

What role does the issue of curriculum content play in the Pro and Against positions? In order to discuss this question, it has to be related to the overall argument for each position. For the Pro statements, we ask: What are the aims that teaching about Romani history and culture is supposed to achieve? What and from where should the knowledge about Romanies be disseminated? What curriculum content should be given to the category of Romani and national minority? For the Against position, the questions have to be asked differently: What are the problems that dissemination of knowledge about Romani has created? What are the controversies that the curriculum content produces? We further relate our discussion to the two contexts that we have mentioned above, the politics of historical justice and multiculturalism in education.

For the Pro position, the need for strengthening the knowledge dissemination about Romani, builds on one of the conclusions from the NOU, that Romani are excluded from society and are still experiencing discrimination in different areas in society. The reason for this situation is articulated as the existence of prejudices or stereotypes about Romani and peoples' ignorance of Romani history and culture (NOU 2015: 7, p. 137). A formulation that reoccurs in several hearing statements is: "Dissemination in schools are important. Students' and teachers' knowledge about the [Romani] people is absent." The main instrument for changing this situation is the school curriculum. The argument thus goes, that if children and youth are learning about who the Romani really were and are, and what they have historically endured, prejudices and ignorance in the majority society will be challenged and changed. It will thus become easier for Romanies to come forward and express their identity publicly.

The political ideal that the Pro position seems to be pointing towards can be described as the multicultural ideal: a pluralistic society where cultural and ethnic identities are acknowledged and tolerated (Kymlicka, 1995). The Pro position's main instrument to achieve this situation is through the curriculum, which will educate about where the Romanies came from, who they were, how they have been treated in society, and further, who they are today. This position rests on two assumptions.

The first assumption is an essentialist notion of ethnic identity. If the minority is to be acknowledged and tolerated, it has to possess particular cultural differences from the majority, which there can be produced knowledge about, and which further can be disseminated in society. The second assumption is that dissemination of the group's essential differences from the majority society, for example in the form of their language or cultural traits, will lead to an understanding and acceptance of these differences and of the identity. These assumptions become clear if one considers the content of the teaching material, teacher resources and the museum exhibition, that are brought forward as good examples in these 
hearings. They can all be said to disseminate narratives that highlight the particular differences of Romani culture in positive and often quite essentialising ways (Kalsås, 2015, 2018).

Disseminating knowledge about minoritised groups is an approach for achieving social justice in an educational context that can be found in many countries (Kumashiro, 2002; Gorski, 2006; Kalsås, 2018). But it is an approach which has come under criticism from a variety of positions. As Kevin Kumashiro (2002) points out, the approach might end up strengthening the process of "othering". At the centre of this approach is still a eurocentric tradition of desiring knowledge about "the other", where the knowledge production and dissemination are simultaneously producing and manifesting the subject that holds this knowledge (Said, 1979; Spivak, 1993). The Pro position's underlining of self-representation does not change this structure: The students' prejudices and misconceptions will be transformed by learning the "true" and "authentic" knowledge about the Romani, but this still positions the student as the subject that will search for this "true" knowledge, and in this move it also excludes the subject from "the other" (Žižek, 2008, pp. 68-71).

These assumptions will potentially have further consequences for how questions of difference, identity and racism are treated more broadly within the curriculum. If the problem is framed as one of ignorance and prejudices, the solution the curriculum can contribute towards, is one of adding content. But this will potentially also mean that alternative approaches are opted out, such as questioning the historical and contemporary practices of excluding the culturally different, approaches that investigate how and why different groups have been and are excluded and marginalised in our society, or to explain this exclusion with economic or ideological power structures (see also Helakorpi, 2019).

When the issue is framed in this way, the question further becomes what knowledge and knowledge produced by whom? The hearing submission from the Directorate of Education might serve as an example of how many of the public institutions approached this issue. The Directorate highlights the work they have done so far to improve the situation by financing teaching material and producing a booklet for teachers about national minorities. Both the booklet and the teaching materials disseminate knowledge that focuses on the specific differences of Romani culture, in addition to a narrative about the state's oppression of the Romanies and their culture (Kalsås, 2018).

In the statements that are written from a Romani position, there is a larger emphasis on the need for an insider perspective in the knowledge produced. The knowledge needs to be produced by Romani and, to the extent that it is possible, disseminated to students by individuals with a Romani identity. As mentioned, this emphasis on authentic voices and self-representation will not necessarily challenge the process of othering, but it will open up the educational arena for struggles to define the Romani identity, where some Romani will be in a position 
to define what the authentic and true knowledge about Romani culture and history is.

In addition to knowledge about the Romani, several Pro submissions are emphasising the need to disseminate the knowledge that the NOU 2015: 7 Assimilation and Resistance has produced about the state's destructive assimilation policy towards the Romani. These submissions express a need for an explanation of why Romani are still experiencing discrimination and why there still exists prejudice. The explanation is found in the past and in the Norwegian state's policy of assimilation. By disseminating a narrative of the state's oppression of the Romani through the curriculum, it presents an explanation of the exclusion of Romani from society that does not point towards the Romani's cultural difference as the problem, but rather towards the state's policy based on notions of homogeneity.

This argument is common in many different contexts where the question of historical justice has been central, and rests on a "memory of offence" (Bevernage, 2010, p. 116) where past injustices are not confined to the past, but constantly "haunts" the present. Acknowledging the past injustice can thus become a way to counteract the continuous consequences of past oppression and violence and strive towards social justice. However, this argument also places the Romani in a continuous position of the victim, not only in the past but also in the present. This positioning and the inability it creates for making a clean break from the past, is something several of the Against statements are problematising.

In the novel History of Violence, Éduard Louis writes about how an event of rape is experienced by the victim when the event is narrated by others, such as family, friends, or by members of institutions such as the police or health services. In one passage, the protagonist has an inner dialogue in response to his friends urging him to report the rape to the police:

\footnotetext{
But you're not the one who'll have to pay, you don't have to pay all over again, you don't have to sacrifice yourself, it's somebody else's turn, don't listen, tear out his tongue so he'll stop, cut out his tongue, you don't need to pay a second time, I thought, Why should the losers have to bear witness to history - as if being the losers weren't enough, why should the losers have to bear witness to their loss, why should they wear themselves out repeating the story of their loss, and go on repeating it even then, I'm nobody's keeper, it's not fair, and I thought, without ever saying a word: No, it's just the opposite of what they say, you should have the right to remain silent, those who have survived violence should have the right to keep it to themselves, they alone should have the right to silence, it's the others whom we should blame for not speaking up. (Louis, 2018, pp. 160-161)
}

There are of course obvious differences between an individual's attempt to deal with experience of traumatic violence in the recent past and a collective dealing with violence directed at them as a collective in a historical past, but this passage can still be read as an analogy for an argument that reoccurs in many of the Against statements. The submissions seem to suggest that the school curriculum is 
collectively positioning the Romani as continuous victims of the state's harsh assimilation policies; the Romani are thus put in the position as witnesses for this act of violence. By disseminating narratives of the Romani's former cultural specificities and the state's attempt and partly success at destroying this culture, the role of the Romani becomes that of the witness, and their right to silence is removed. What several of the Against statements seem to be arguing for, is the right of the Romani to be silent, move on, and not have to dwell on this past.

However, the Against position is going further and arguing against any kind of knowledge about Romani culture and identity in the curriculum. By bringing the Romani culture and history into public view, and focusing on their differences as a national minority, the Romani also become visible in the public eye, and possibly also in the classroom. Since the Romani are no longer necessarily a visible minority in society, expressing an identity as Romani has to a certain extent been an individual choice, and a choice that can vary in different social contexts. Several of the Against submissions point out that the focus on Romani culture in the classroom can and has led to an exotification of the Romani, which will contribute to the labelling of children from a Romani background as "the other". The past is evoked, but this time as a reference for how the children can become excluded and bullied in school.

The notion of Romani identity that the Against position is scathing about, is one based on private family relation and community, but which is hidden to the general public. Thus it challenges a minority policy based on the category of "national minority", whose prerequisite is a public acknowledgement of the minority's identity. The Against position highlights a dilemma in the Norwegian approach to multicultural education: If the schools and the curriculum shall contribute to multicultural nation building, then there is a need for certain bordered and named minorities which can be displayed and acknowledged in the classroom. And there is a need for witnesses to the state's former "harsh assimilation policies", which the contemporary multicultural policy can be contrasted against and create a form of legitimacy for. The Against statements can thus be read as a counter-discourse against the Romani being used and positioned (once again) as "the other", even if it is as a celebrated and included "other".

Our analysis illuminates that the Pro position and the NOU 2015: 7 Assimilation and Resistance argument about strengthening the curriculum content about Romani, can be understood as the result of a contingent process where the politics of historical justice and multiculturalism in education have been interwoven, producing a discourse where teaching about the Romani as a different and distinct minority culture and about the state's oppression of this minority, will contribute towards a social justice in education and society. But this dominant discourse, widely applied by central institutions in education, has also contributed to the formation of a counter-discourse, which takes a subject position as Romani and uses the curriculum as an instrument for objecting to dominant arguments in the policies of national minorities and historical justice. 


\section{Conclusion}

In this article, we have looked at how the issue of the school curriculum became a controversial issue in the political hearing process after the publication of the Green Paper NOU 2015: 7 Assimilation and Resistance. Our analysis has illuminated the two main positions taken on the NOU. Neither of the positions denies the historical atrocities presented in the Green Paper, but they draw different conclusions for how the Romani should be positioned in society. For each of these positions, the curriculum has a specific significance and meaning. In the hearing submissions that supported the findings in NOU 2015: 7, knowledge about the Romani in the curriculum is constructed as a vital tool in order to make the Romani visible in society and as an important step for achieving historical and social justice. This approach presupposes a coherent minority of which knowledge can be produced and disseminated in school. This is contested by the hearing submissions that are against the suggestions and publication of the NOU 2015: 7, which see the curriculum content as a way to force the Romani to become a visible "other", with negative consequences for the minority in general and particularly the children. It is noteworthy that although the Against position asks to be left alone and to emphasise their Norwegian-ness, they also point out that being "the other" in Norwegian schools is a dangerous position to be in. This indicates the insufficiency of current multicultural approaches and that it is still better to be treated as "Norwegian" in Norwegian schools.

As mentioned in the introduction, there has been a tendency in part of the research on cultural difference and majority-minority relations in the Norwegian school system, to take the category of national minority as a precondition and present a minority subject with common interests and intentions. Our analysis of the hearing submissions highlights the limitations and problematic aspects of taking this precondition as a starting point. What the hearing shows, is that within one such national minority, the Romani, there are a diversity of voices that take the subject position as Romani, and which present conflicting views and interests. Our suggestion for further research in this field is that rather than taking such categories as pre-given, they should be unpacked and critically investigated in different educational contexts.

The findings in our study can also be read as an argument about what empirical data and analytical delimitations that should be considered in the field of didactical research on controversial issues in education. The field should not be limited to focusing on questions about how controversial issues can or should be tackled in the classroom, but we should also ask questions about which issues are brought into the curriculum and why these issues are framed as controversial for the school to tackle in the first place. The field also needs to consider how the issues expressed in the curriculum are contingently formed by contexts outside of educational policy, and how the curriculum thus becomes interwoven into these contexts. 


\section{About the authors}

Vidar Fagerheim Kalsås is a researcher at The Norwegian Center for Holocaust and Minority Studies. In his doctoral thesis (2018), he examines the historical narratives about Romani and Roma that are conveyed to students in Norwegian and Swedish schools. His research interests concern minority history, minority politics, racism, historical culture and history didactics. Institutional affiliation: The Norwegian Center for Holocaust and Minority Studies, Villa Grande, Huk aveny 56, Oslo, Norway.

E-mail: v.f.kalsas@hlsenteret.no

Jenni Helakorpi is a university lecturer in education at the University of Helsinki. In her doctoral thesis (2020) she studied the policies and practices that aim to promote the education of Roma and Travellers in Finland, Sweden and Norway. Her research interests focus on justice in education, marginalisation, minoritised groups, racism and whiteness, and ethnographic methodologies.

Institutional affiliation: Department of Education, University of Helsinki, PL 9 (Siltavuorenpenger 1A), 00014 University of Helsinki, Finland.

E-mail: jenni.helakorpi@helsinki.fi

\section{References}

Allemann-Ghionda, C. (2009). From intercultural education to the inclusion of diversity: Theories and policies in Europe. In J. A. Banks (Ed.), The Routledge International Companion to Multicultural Education (pp. 134-145). New York: Routledge.

Askeland, N., \& Aamotsbakken, B. (2016). Folk uten land? - Å gi stemme og status til urfolk og nasjonale minoriteter [People Without Land? - To Give Voice and Status to Indigenous Peoples and National Minorities]. Kristiansand: Portal.

Bangstad, S. (2011). Multikulturalismen og dens kritikere [Multiculturalism and its Critics]. In B. P. Bø (Ed.), Multikulturell teori og flerkulturelle praksiser: Artikler om norsk minoritetspolitikk [Multicultural Theory and Multicultural Practices: Articles about Norwegian Minority Policy] (pp. 21-45). Oslo: Abstrakt forlag.

Banks, J. A. (2009). Multicultural Education: Dimensions and Paradigms. In J. A. Banks (Ed.), The Routledge International Companion to Multicultural Education (pp. 9-32). New York: Routledge.

Bevernage, B. (2010). Writing the past out of the Present: History and the Politics of Time in Transitional Justice. History Workshop Journal, 69(1), 111-131.

Bevernage, B. (2015). The Past Is Evil/Evil Is Past: On Retrospective Politics, Philosophy of History, and Temporal Manichaeism. History and Theory, 54(3), 333-352. https://doi.org/10.1111/hith.10763

Brochmann, G. (2002). Velferdsstat, integrasjon og majoritetens legitimitet [The Welfare State, Integration and the Majority's Legitimacy]. In G. Brochmann, T. Borchgrevink, \& J. Rogstad (Eds.), Sand i maskineriet. Makt og demokrati i det flerkulturelle Norge [Sand in the Machinery. Power and Democracy in Multicultural Norway] (pp. 27-55). Oslo: Gyldendal Akademisk. 
Council of Europe (1995). Framework Convention for the Protection of National Minorities. European Treaty Series - No. 157. Strasbourg.

Gillborn, D. (2006). Critical Race Theory and Education: Racism and antiracism in educational theory and praxis. Discourse, 27(1), 11-32.

Gorski, P. C. (2006). Complicity with conservatism: The de-politicizing of multicultural and intercultural education. Intercultural Education, 17(2), 163-177. https://doi.org/10.1080/14675980600693830

Haave, P. (2017). Hovedtrekk i norsk romani-/taterpolitikk: Assimilering [The Main Features in Norwegian Romani Policy: Assimilation]. In N. Brandal, A. C. Døving, \& I. T. Plesner (Eds.), Nasjonale minoriteter og urfolk i norsk politikk fra 1900 til 2016 [National Minorities and Indigenous Peoples in Norwegian Policy from 1900 to 2016] (pp. 95-112). Oslo: Cappelen Damm akademisk.

Hall, S. (2000). The Multicultural Question. In B. Hesse (Ed.), Un/Settled Multiculturalisms: Diasporas, Entanglements, Transruptions (pp. 209-240). London: Zed Books.

Halvorsen, R. (2004). Taternes arbeid for oppreisning og anerkjennelse i Norge [The Romanies' Work for Compensation and Recognition in Norway]. Trondheim: Tapir akademisk forlag.

Helakorpi, J. (2019). Knowledge about Roma and Travellers in Nordic Schools: Paradoxes, Constraints, and Possibilities. In S. Keskinen, U. D. Skaptadóttir, \& M. Toivanen (Eds.), Undoing homogeneity in the Nordic region: Migration, difference and the politics of solidarity (pp. 69-87). Routledge.

Helakorpi, J. (2020). Innocence, Privilege and Responsibility: Power relations in policies and practices on Roma, Travellers and basic education in three Nordic countries. Doctoral dissertation, University of Helsinki. Helsinki Studies in Education, number 83.

https://helda.helsinki.fi/bitstream/handle/10138/317940/innocenc.pdf?sequence=1\&isAllo wed $=\mathrm{y}$

Hvinden, B. (Ed.) (2000). Romanifolket og det norske samfunnet: følgene av hundre års politikk for en nasjonal minoritet [Romani and the Norwegian Society: The Consequences of a Century of Policy for a National Minority]. Bergen: Fagbokforlaget.

Kalsås, V. F. (2015). Minority history in museums. Between ethnopolitics and museology. Nordisk Museologi, 2, 33-48.

Kalsås, V. F. (2018). Forteljingar om eigenart og undertrykking: Ein studie av undervisningstekstar om minoritetane romanifolket og romar [Narratives about Distinctiveness and Oppression: A Study of Educational Texts about the Minorities Romani and Roma]. Doctoral dissertation, University of Agder. http://hdl.handle.net/11250/2577255

Kumashiro, K. K. (2002). Troubling Education: "Queer" Activism and Anti-Oppressive Pedagogy. Routledge.

Kymlicka, W. (1995). Multicultural Citizenship: A Liberal Theory of Minority Rights. Oxford: Clarendon.

Lappalainen, S. H., Nylund, M., \& Rosvall, P.-Å. (2019). Imagining societies through discourses on educational equality: A cross-cultural analysis of Finnish and Swedish upper secondary curricula from 1970 to the 2010s. European Educational Research Journal, 18(3), 335-354.

Louis, É. (2018). History of Violence. London: Vintage Publishing.

Lund, A. B., \& Moen, B. B. (2013). Taterne og skolen - hva må til for å bedre taterbarnas skolesituasjon? [The Romani and the School - What Has to Be Done in Order to Improve the Romani Children's Situation in School]. Norsk pedagogisk tidsskrift, 97(04-05), 259268. 
Midtbøen, A. H., Orupabo, J., \& Røthing, Å. (2014a). Beskrivelser av etniske og religiøse minoriteter i leremidler [Descriptions of Ethnic and Religious Minorities in Textbooks]. Rapport 2014: 010, Institutt for samfunnsforskning, Oslo. https://samfunnsforskning.brage.unit.no/samfunnsforskning-xmlui/handle/11250/2374743

Midtbøen, A. H., Orupabo, J., \& Røthing, Å. (2014b). Etniske og religiøse minoriteter i laremidler: Lerer-og elevperspektiver [Ethnic and Religious Minorities in Textboks: Teacher and Student Perspectives]. Rapport 2014: 011, Institutt for samfunnsforskning, Oslo. https://samfunnsforskning.brage.unit.no/samfunnsforskning-xmlui/handle/11250/2387339

Ministry of Foreign Affairs (1998). Om samtykke til ratifikasjon av Europarådets rammekonvensjon av 1. februar 1995 om beskyttelse av nasjonale minoriteter [Ratification of the Council of Europe's Framework Convention for the Protection of National Minorities]. St.prp. nr, 80 (1997-98). https://www.regjeringen.no/no/dokumenter/stprp-nr-80-199798-/id202013/

Ministry of Local and Regional Affairs (2000). Nasjonale minoritetar i Noreg - Om statleg politikk overfor jødar, kvener, rom, romanifolket og skogfinnar [National Minorities in Norway - about State Policy towards Jews, Kvens, Roma, Romani and Forest Finns]. St.meld. nr. 15 (2000-2001). https://www.regjeringen.no/no/dokumenter/stmeld-nr-152000-2001-/id585195/

Ministry of Local and Regional Affairs (2001). Om samepolitikken [About the Sami Policy]. St.meld. nr. 55 (2000). https://www.regjeringen.no/no/dokumenter/stmeld-nr-55-20002001-/id195308/?ch=1

Ministry of Local Government and Modernisation (2015). Høringsbrev - NOU 2015: 7 Assimilering og motstand - Norsk politikk overfor taterne/romanifolket fra 1850 til i dag [Letter for Public Hearing - NOU 2015:7 Assimilation and Resistance - Norwegian policies towards Tater/Romani people from 1850 to the present]. https://www.regjeringen.no/no/dokumenter/horing---oppfolging-av-tater-romaniutvalgetsrapport/id2464464/?expand=horingsbrev

Moen, B. B. (2009). Taterne og skolen - et asymmetrisk møte [Romani and the School - an Asymmetric Encounter]. Norsk pedagogisk tidsskrift, 93(03), 226-238.

Moen, B. B., \& Lund, A. C. B. (2010). Nasjonale minoriteter i det flerkulturelle Norge [National Minorities in Multicultural Norway]. Trondheim: Tapir akademisk forlag.

Morken, I. (2009). Mangfold, inkludering og minoritetshierarki i nasjonale læreplaner [Diversity, Inclusion and Minority Hierarchy in National Curricula]. In E. L. Dale (Ed.), Lcereplan: et forskningsperspektiv [Curricula: A Research Perspective] (pp. 154-186). Oslo: Universitetsforlaget.

Neumann, K., \& Thompson, J. (Eds.) (2015). Historical justice and memory. Madison: UW Press.

Niemi, E. (2017). Fornorskingspolitikken overfor samene og kvenene [The Norwegianisation Policy Towards the Sami and the Kvens]. In N. Brandal, A. C. Døving, \& I. T. Plesner (Eds.), Nasjonale minoriteter og urfolk i norsk politikk fra 1900 til 2016 [National Minorities and Indigenous Peoples in Norwegian Policy from 1900 to 2016] (pp. 131152). Oslo: Cappelen Damm Akademisk.

NOU 2015: 7 (2015). Assimilering og motstand - Norsk politikk overfor taterne/romanifolket fra 1850 til i dag [Assimilation and Resistance - Norwegian policies towards Tater/ Romani people from 1850 to the present]. https://www.regjeringen.no/no/dokumenter/nou-2015-7/id2414316/

Pettersen, K. S. (2005). Tatere og misjonen : mangfold, makt og motstand [The Romani and the Mission: Diversity, Power and Resistance]. Doctoral thesis, Norsk institutt for forskning om oppvekst, velferd og aldring, Oslo.

Said, E. W. (1979). Orientalism. New York: Vintage. 
Schjetne, E., \& Skrefsrud, T. (Eds.) (2018). A væere læerer i en mangfoldig skole: kulturelt og religiøst mangfold, profesjonsverdier og verdigrunnlag [Being a Teacher in a Diverse School: Cultural and Religious Diversity, Professional Values and the Basis for Values]. Oslo: Gyldendal.

Spivak, G. C. (1988). Subaltern Studies: Deconstructing Historiography. In G. C. Spivak (Ed.), In other worlds: Essays in cultural politics (pp. 197-221). Routledge.

Spivak, G. C. (1993). “Can the Subaltern Speak?” In P. Williams \& L. Chrisman (Eds.), Colonial Discourse and Post-Colonial Theory: A Reader (pp. 66-111). New York: Harvester Wheatsheaf.

Taylor, C. (1992). The Politics of Recognition. In C. Taylor (Ed.), Multiculturalism and the Politics of Recognition (pp. 25-74). Princeton University Press.

Tellmann, S. A. (2018). Norges Offentlige Utredninger - mellom forskning og politikk [Norwegian Official Reports - Between Research and Politics]. In K. Bjørkdahl (Ed.), Rapporten: Sjanger Og Styringsverktøy [The Report: Genre and a Governing Tool]. Oslo: Pax.

Utdanningsdirektoratet (2006a). Læreplan i samfunnfag (SAF1-01) [Curriculum in Social Sciences]. http://data.udir.no/kl06/SAF1-01.pdf

Utdanningsdirektoratet (2006b). Lcereplan i historie - fellesfag i studieforberedende utdanningsprogram (HIS1-01) [Curriculum in History - Common Subject in the Educational Program for Preparation to Higher Education]. http://data.udir.no/kl06/HIS1-01.pdf

Utdanningsdirektoratet (2014). Våre nasjonale minoriteter - Til ansatte i barnehager og skoler [Our National Minorities - To Employees in Kindergartens and Schools]. https://www.udir.no/globalassets/filer/laringsmiljo/nasjonaleminoriteter/nasjonale_minoriteter_udir.pdf

Westrheim, K., \& Tolo, A. (Eds.) (2014). Kompetanse for mangfold: Om skolens utfordringer i det flerkulturelle Norge [Competence for Diversity: About the School's Challenges in Multicultural Norway]. Bergen: Fagbokforlaget.

Westrheim, K., \& Hagatun, K. (2015). Hva betyr «kompetanse for mangfold» i utdanningssystemet? - Et kritisk perspektiv på mangfolddiskursen [What Does «Competence for Diversity» mean in the Educational System? - A Critical Perspective on the Diversity Discourse]. Norsk Pedagogisk Tidsskrift, 99(03-04), 168-180.

Žižek, S. (2008). The Sublime Object of Ideology. London: Verso. 